\title{
Bacterial Colonization as a Possible Source of Overactive Bladder Symptoms in Pediatric Patients: A Literature Review
}

\author{
Katarzyna Kilis-Pstrusinska ${ }^{1, *(0)}$, Artur Rogowski ${ }^{2,3}$ and Przemysław Bienkowski ${ }^{4}$ \\ 1 Department of Pediatric Nephrology, Wroclaw Medical University, Borowska 213, 50-556 Wroclaw, Poland \\ 2 Faculty of Medicine, Cardinal Stefan Wyszyński University in Warsaw, Collegium Medicum, \\ Kazimierza Wóycickiego 1/3, 01-938 Warsaw, Poland; arogowski@op.pl \\ 3 Department of Obstetrics and Gynecology, Mother and Child Institute, 01-211 Warsaw, Poland \\ 4 Department of Psychiatry, Medical University of Warsaw, Nowowiejska 27, 00-665 Warsaw, Poland; \\ pbienko@yahoo.com \\ * Correspondence: katarzyna.kilis-pstrusinska@umed.wroc.pl; Tel.: +48-71-7364400; Fax: +48-71-7364409
}

check for updates

Citation: Kilis-Pstrusinska, K.; Rogowski, A.; Bienkowski, P. Bacterial Colonization as a Possible Source of Overactive Bladder Symptoms in Pediatric Patients: A Literature Review. J. Clin. Med. 2021, 10, 1645. https://doi.org/10.3390/ jcm10081645

Academic Editors: Michael Stöckle and Katarzyna Taranta-Janusz

Received: 4 March 2021

Accepted: 9 April 2021

Published: 13 April 2021

Publisher's Note: MDPI stays neutral with regard to jurisdictional claims in published maps and institutional affiliations.

Copyright: (c) 2021 by the authors. Licensee MDPI, Basel, Switzerland. This article is an open access article distributed under the terms and conditions of the Creative Commons Attribution (CC BY) license (https:/ / creativecommons.org/licenses/by/ $4.0 /)$.

\begin{abstract}
Overactive Bladder $(\mathrm{OAB})$ is a common condition that is known to have a significant impact on daily activities and quality of life. The pathophysiology of OAB is not completely understood. One of the new hypothetical causative factors of $\mathrm{OAB}$ is dysbiosis of an individual urinary microbiome. The major aim of the present review was to identify data supporting the role of bacterial colonization in overactive bladder symptoms in children and adolescents. The second aim of our study was to identify the major gaps in current knowledge and possible areas for future clinical research. There is a growing body of evidence indicating some relationship between qualitative and quantitative characteristics of individual urinary microbiome and OAB symptoms in adult patients. There are no papers directly addressing this issue in children or adolescents. After a detailed analysis of papers relating urinary microbiome to $\mathrm{OAB}$, the authors propose a set of future preclinical and clinical studies which could help to validate the concept in the pediatric population.
\end{abstract}

Keywords: overactive bladder; urinary microbiome; children; adolescents

\section{Introduction}

Overactive Bladder $(\mathrm{OAB})$ is a common condition that is known to have a significant impact on daily activities and quality of life [1-4]. In the pediatric population, OAB may not only burden child development but also have a negative impact on the family situation $[5,6]$. OAB is a form of lower urinary tract dysfunction caused by involuntary detrusor contractions during the filling phase. It is characterized by urgency and increased voiding frequency with or without incontinence in the absence of urinary tract infection [7]. $\mathrm{OAB}$ is not associated with neurological and anatomical alterations of the lower urinary tract. The recent International Children's Continence Society (ICCS) document proposes using the term daytime lower urinary tract (LUT) conditions to group all functional bladder problems in children [8]. OAB is the second most common bladder dysfunction following nocturnal enuresis [9]. Comorbid conditions associated with bladder dysfunction include urinary tract infections, vesicoureteral reflux, constipation, and encopresis [1,9-11]. In addition, there appears to be an increased frequency of behavioral and neurodevelopmental issues $[5,6]$. One should bear in mind that the course and clinical picture of OAB in children differ substantially from that observed in adult patients. On a theoretical ground, there are several unique factors to consider in the context of pediatric $\mathrm{OAB}$, including the role of general child development, mode of delivery, mother microbiome, maturation of the nervous and endocrine systems, and development of the urinary tract [12-16].

The overall OAB prevalence in the pediatric population ranges from $1.5 \%$ to $36.4 \%$ [17-19]. It is known that the peak incidence occurs between 5 and 7 years of age, with a higher prevalence in males [1,12,20]. Overactive bladder decreases with age [13,21]. Results of a 
cross-sectional survey of 19,240 Korean schoolchildren identified the overall incidence of $\mathrm{OAB}$, defined as urgency with or without incontinence, was $17 \%$. The highest incidence of $23 \%$ was noted in five-year-old children and the lowest (12\%) in 13-year-old patients [17]. Although OAB can resolve itself spontaneously, urinary symptoms can persist into adulthood $[14,22]$. The prevalence estimates for urge UI ranged from $1.8 \%$ to $30.5 \%$ in the European population, from $1.7 \%$ to $36.4 \%$ in the US population, and from $1.5 \%$ to $15.2 \%$ in the Asian population [2].

The pathophysiology of $\mathrm{OAB}$ is not completely understood and is believed to be multifactorial [15,23-26]. One proposed hypothesis is that dysbiosis of an individual urinary microbiome could induce or potentiate $\mathrm{OAB}$ symptoms [16,27-30]. The major aim of the present review was to identify data supporting the role of bacterial colonization in overactive bladder symptoms in children and adolescents. The second aim of our study was to identify major gaps in current knowledge and possible areas for future clinical research.

\section{Methods}

The present work was not intended to directly answer a well-defined clinically meaningful question or to modify current practice and thus could hardly fulfill the definition of a systematic review. The paucity of clinical data and lack of randomized clinical trials on the role of the microbiome in overactive bladder symptoms in children precluded a meaningful scoping review approach [31]. Hence, the present review was designed as a narrative mini-review with an assumption that an increase in the number of full-text papers may allow us to use a scoping or systematic review approach in the future [32].

Full-text papers focused on the association between the microbiome and overactive bladder symptoms were identified by searching MEDLINE and Google Scholar from inception to December 2020. Keywords included the following terms: "bacterial colonization" OR "microbiome" OR "urobiome" OR "dysbiosis" AND "overactive bladder" OR "urgency" OR "urge incontinence". A manual search of reference lists of relevant papers was also performed. One hundred and fifty-six papers were identified and screened for eligibility. Twelve original studies on microbiome and $\mathrm{OAB}$ were finally included in the review process. All efforts were made to identify studies on the pediatric population through manual search of abstracts and method sections for the age of recruited subjects.

Three independent reviewers screened abstracts for eligibility. Clinical studies on human subjects written in English with an available full text were included. Book chapters and conference abstracts were checked but excluded if not followed by a full-text publication.

\section{Theoretical and Clinical Background}

\section{1. $O A B$}

The pathophysiology of $\mathrm{OAB}$ is not completely understood and is believed to be multifactorial $[24,25,29,33]$. One theory is that the urgency and related symptoms stem from a cortical immaturity of the centers responsible for controlling urination [15,34]. Voluntary and coordinated urination is developed over time. In the first year of life, voiding is mainly controlled by the brainstem [35]. Then, cortical inhibitory pathways and the pontine micturition center along with periaqueductal grey matter, anterior cingulate gyrus, and the autonomic, somatic, and sensorial autonomic nervous systems are developed, and urination becomes voluntary [36]. The prefrontal cortex starts to maintain top-down control over more primitive afferent pathways of the brain, such as the limbic and paralimbic systems [24].

Another concept, the so-called "bladder-brain dialogue", suggests a mutual interaction between the brain and the bladder rather than unidirectional control by the brain $[26,33,36]$. The role of inflammation in $\mathrm{OAB}$ is also under investigation [25,37]. Bladder biopsies from patients with OAB without urinary tract infection (UTI) showed inflammatory changes [38]. Ghoniem et al. demonstrated upregulation of a selective subset of proinflammatory cytokines and chemokines in patients with OAB [39]. Urgency is attributed to abnormal neuromuscular signaling resulting from the stimulation of cholinergic receptors, which 
causes involuntary bladder muscle contractions [40,41]. However, in urodynamic studies, detrusor overactivity was only observed in approximately $58 \%$ of women with urge UI [42]. Therapy with anticholinergic drugs which mainly inhibit the function of efferent neurons in the detrusor muscle is ineffective for approximately half of patients that use them [43]. Comparable observations have been made concerning children. In case series of children with voiding dysfunction symptoms, detrusor overactivity detected by urodynamic testing was present in $52 \%$ to $58 \%$ of patients compared with $5 \%$ to $18 \%$ of asymptomatic children $[44,45]$. Moreover, a prospective multicenter study reported a poor correlation between symptoms and urodynamic testing in children with incontinence [46]. In a study by Bael et al., 60 of 91 children with urgency did not have evidence of an overactive bladder during bladder filling when urodynamic testing. In addition, there was a poor correlation between urodynamic findings and the response to the treatment [46].

An active exploration of etiological factors and pathophysiological mechanisms standing behind $\mathrm{OAB}$ symptoms in children is a prerequisite for developing safe and efficacious treatment strategies.

\subsection{Microbiome}

The term microbiome refers to the bacterial milieu present within various environment niches. Each individual's microbiome is unique and adapts during life as a result of environmental and genetic influences $[47,48]$. The maternal microbiome is a dominant factor in the development of the neonatal skin, oral mucosa, and nasopharyngeal microbiome, regardless of the delivery mode $[49,50]$. In the next period of life, the maternal microbiome further affects the child's microbiome through multiple transmission routes. What is interesting is a metatranscriptomic analysis of bacterial strains specific to mother-infant pairs suggests that gastrointestinal bacteria were not only transferred from the maternal gut to the infant gut environment but that the bacteria adapted effectively to the infant gut [50].

The microbiome can assist in maintaining healthy states in the human body including homeostasis and immune defense [48]. On the other hand, alterations to the microbial community structure may be also implicated in disease [51,52].

\subsection{Urinary Microbiome}

In the past, the urinary tract (without urethra) was considered to be sterile under normal conditions. The advances in bacterial assessment in the past decade, particularly $16 \mathrm{~S}$ rRNA gene sequencing and expanded quantitative urine culture (EQUC), have shown that the urinary tract is not sterile $[27,28,38,52-55]$. Up to $80 \%$ of bacteria can be isolated using modified culture techniques for a sample that has been classified as having no growth according to the standard method [54]. According to an analysis of the literature performed by Morand et al., the urinary tract bacterial microbiome contains $21.4 \%$ of the known prokaryotic diversity associated with human beings (464 species in common), and it shares $23.6 \%$ of species with the human gut microbiota (350 species in common, $62.3 \%$ of the urine species) [56]. Females have predominantly Lactobacillus and Gardnerella species, while males carry Corynebacterium, Staphylococcus, and Streptococcus as dominant species [38,55]. In addition, females tend to have a more heterogeneous urinary microbiome. The species found in urine can be pathogenic or commensal. At least $60.0 \%$ of the urine microbiota is not reported in the literature as causing human UTI [56].

The characteristics and role of urinary microbiota are currently debated [33,51,52]. Urinary tract microbiota influences UTI $[16,57,58]$. Modification of bacterial components in urine has been associated with kidney stones, bladder cancer, and urinary incontinence $[16,27,51,59]$. In the context of the urinary microbiome, the gut and vaginal microbiome are also of interest, since there is evidence that implies that there is some degree of cross-talk between the bacterial flora of these organs [60-63].

The majority of urinary microbiome studies focus on adult subjects and papers concerning children are scarce. The pediatric studies on the urinary microbiome are collected in Table 1 . The natural history of the urinary microbiome remains mostly unexplored. 
However, to understand the role of the urinary microbiome in disease states, both in children and adults, it is necessary to know what may constitute a healthy urinary microbiome and how it develops in early childhood.

Table 1. Pediatric studies of the urinary microbiome.

\begin{tabular}{cl}
\hline \multicolumn{1}{c}{ Study Group: Age, $n$} \\
\hline \\
\\
60 female children divided into four \\
developmental groups: $0-3 \mathrm{~m} / \mathrm{o}(n=15)$, \\
& $4-10 \mathrm{~m} / \mathrm{o}(n=15), 2-6 \mathrm{y} / \mathrm{o}(n=15), 7-12 \mathrm{y} / \mathrm{o}$ \\
& premenstrual girls $(n=15)$
\end{tabular}

Significant shifts in the perianal and periurethral/perivaginal (PUPV) microbiome compositions during childhood, corresponding to important developmental milestones. Significant differences in the PUPV microbiome of girls with a history of UTI, likely influenced by both the UTI and the antibiotic exposure.

Curley et al. [58] Review

Review of the literature on the role of the microbiome in recurrent UTIs, focusing on female pediatric patients when able.

34 children with neuropathic bladders with

Forster at al. [65] UTI ( $n=11$, mean age $11 \mathrm{y} / \mathrm{o})$, ASB $(n=19$, mean age $8.8 \mathrm{y} / \mathrm{o})$, and with negative urine culture $(n=4$, mean age $15 \mathrm{y} / \mathrm{o})$
The most predominant bacteria in the urine microbiomes are from the Enterobacteriaceae family. No difference in the urine microbiome between children with UTI, ASB, and negative urine cultures. Route of catheterization may affect the composition of the urine microbiome.

Urinary microbiome was identified in every child, even in 3 subjects less than 30 days of age. Changes in microbiome diversity and composition were observed in subjects with a standard culture-positive UTI.
85 children $<48$ months of age (72 less than 24 months)

subjects with a standard culture-positive UTI.

The first characterizations of the urinary microbiome in prepubertal males. Defining the baseline healthy microbiome in children may lay the foundation for understanding the long-term impact of factors such as antibiotic use in the development of a healthy microbiome as well as the development of future diseases.

After bladder augmentation, the native urinary bladder and augmented intestinal segments host similar microbiota despite their distinct differences of originating mucosal anatomy. Age at sampling had a statistically significant influence on $\beta$-diversity at the genus level.

Review of the literature on the effects of the microbiome on urologic diseases that affect the pediatric patient, including UTI, urge urinary incontinence/overactive bladder, and urolithiasis.

No difference in taxa richness, evenness, or community composition between cases and controls or for gestational age modeled as a continuous variable.
49 cases (delivery $<37$ weeks gestation) and 48 controls (delivery $\geq 37$ weeks gestation)

UTI-urinary tract infection; ASB-asymptomatic bacteriuria.

The relation between the urinary microbiome of parents and their children is largely unknown because to date no study has directly addressed this topic. Given the anatomic relationship between the vagina and the urinary tract, the vaginal microbiome may be relevant to the urinary microbiome. However, Hickey et al. stated that the vaginal microbiome of adolescent girls was not compatible with that of their mothers [60]. This suggests, as was the case with the gut microbiome, that the acquisition of the female "adult-form" microbiome is more of a maturation of the microbiome rather than a transition in the species representation. Currently, the data concerning the vaginal microbiome of girls are 
not consistent. According to a review paper by Smith and Ravel, the prepubertal vaginal microbiome is dominated by a variety of anaerobes, diphtheroid, coagulase-negative Staphylococci, and E. coli, while the postmenarcheal vaginal microbiome is most similar to adult vaginal microbiomes, dominated by Lactobacillus [61]. However, a prospective longitudinal study of perimenarcheal girls documented that Lactobacillus dominated the vaginal microbiome before the onset of menarche [60]. In addition, Gardnerella vaginalis, classically considered to be pathogenic, was found in up to one-third of perimenarcheal subjects. Probably, these bacteria play a commensal role in the prepubertal period.

The vaginal microbiome can be of importance in an analysis of a healthy urinary microbiome and its dysbiosis or perturbations. Urine, intestinal and vaginal microbiomes are interconnected. For example, intestinal bacteria may colonize the vaginal entrance and periurethra, and then ascend up the urethra to the bladder. The vaginal microbiome may be a natural line of defense against invading uropathogens or it may alter the urinary microbiome [62].

Kinneman et al. [57] assessed the urinary microbiome in children younger than 48 months undergoing a urinary catheterization, with and without UTI. A urinary microbiome was identified in every child. The 5 most abundant families were tissierellaceae, prevotellaeae, veillonellaceae, enterobacteriaceae, and comamonadaceae. The 5 most abundant genera were Prevotella, Peptoniphilus, Escherichia, Veillonella, and Finegoldia. Alpha diversity, which refers to the number of different species in a single site, did not differ by age, gender, antibiotic use 15 days to three months before the urine sample was obtained, maternal ethnicity, country of origin, delivery mode, or probiotic use. Decreased diversity and changes in the compositions of urinary microbiome were observed in children with standard culture-positive UTI. The authors noticed that antibiotic use affected the urinary microbiome only for a short time (up to two weeks).

Kassiri et al. [66] examined the urinary microbiome in 20 prepubertal males (aged 3 months- 8 years; median age 15 months) with and without prior antibiotic exposure. The majority of patients had representation from Staphylococcus and Varibaculum species and to a lesser extent Peptoniphilus and Actinobaculum. Several of the detected genera have been previously identified in the urine of adult men. However, urinary microbial communities profiled in children were different from those described in adults. For example, Staphylococcus and Corynebacterium were present in children but were not dominant. The authors stated that the composition of the urinary microbiome in children may begin to develop early in life and evolve over time, becoming more stable in adulthood. Moreover, the study also showed differences in both the urinary and gastrointestinal microbiome in children with prior antibiotic exposure, confirming the effect of drugs on the child microbiome.

Forster et al. [65] performed a cross-sectional analysis of the urine microbiome of children with neuropathic bladders. Enterobacteriaceae are the most predominant bacteria in the urine microbiomes, along with Staphylococcus, Streptococcus, and Enterococcus. There was no difference in the urine microbiome between children with UTI, asymptomatic bacteriuria, and negative standard cultures. It has been observed that the route of catheterization may affect the composition of the urine microbiome. Children who catheterize their urethra have a higher proportion of Staphylococcus, while the urinary microbiome of patients who catheterize through a Mitrofanoff was composed of Enterobacteriaceae family bacteria.

In summary, the urinary microbiome in the pediatric population has just begun to be explored. Further studies that focus on the potential variables influencing the urinary microbiome are needed.

\subsection{Review of Studies on Urinary Microbiome and $O A B$}

The first studies investigating the urinary microbiome in patients with urgency concerned women suffering from urge UI who had no signs of infection $[53,54]$. Research studies confirmed urinary bacterial DNA and the relation of bladder polymicrobial community to certain clinical variables such as baseline urgency urinary incontinence episodes, treatment response, and post-treatment UTI risk [29]. When comparing women with and 
without urge UI, Gardnerella and Lactobacillus gasseri were associated with urge UI, while Lactobacillus crispatus was detected most frequently in controls, indicating the possibility of a protective effect of Lactobacillus crispatus in preventing the development of urge UI [27]. Karstens et al. revealed that the urine microbiome composition of women with normal bladder function and women with urge UI not only varies in the type of bacteria that are present but also in the number of different bacteria and abundance of these bacteria [69]. Women with more severe urge UI symptoms have decreased microbial diversity in their urinary microbiomes. Moreover, the authors noted that of the nine species found to be overrepresented in the urine of patients with urge UI, five bacteria reported as pathogens causing UTI are not routinely detected by routine cultures. This suggests that a persistent low-grade infection by such bacteria could potentially be responsible for the irritating symptoms of urge UI. In another study, it has been established that the uropathogenic bacteria Proteus was more commonly isolated from women with OAB. On the other hand, the genus Lactobacillus was present less commonly in urine from OAB patients when compared to urine taken from controls [70]. The results are in line with studies describing a significantly greater prevalence of Lactobacillus in controls compared to patients with bladder symptoms. The protective role of Lactobacilli is explained by their ability to produce bacteriocins, which have activity against uropathogenic bacteria [63].

The above-mentioned studies suggest that perturbations in the urinary microbiome, a state referred to as dysbiosis, may predispose to the development of OAB. However, the kind of microbiome diversity connected with OAB is not clear. Thomas-White et al. found that women with urge UI had a different and more diverse microbiome as compared to unaffected women [71]. Among patients treated with solifenacin, an anticholinergic drug, a better response was observed in women with fewer bacteria and a less diverse microbiome whereas non-responders had a community that often included bacteria not typically found in responders. However, in most studies, a decrease in species diversity was associated with urgency UI $[69,70]$.

One should bear in mind that the above studies were cross-sectional in nature and it is not clear whether the differences in the urinary microbiome are the cause or consequences of OAB. It is possible that the urinary frequency typically associated with urgency urinary incontinence alters the microbial community. Significant new findings have highlighted the non-barrier role of the urothelium, especially its sensory functions [24,33,72,73]. As there is clear evidence of communication between the bladder and the brain, it is biologically plausible that the urinary microbiota may play some role in this communication. Therefore, the urothelial sensory signaling and its alteration may be responsible for bladder dysfunction.

\section{Conclusions and Future Directions for Studies on Urinary Microbiome and Pediatric OAB}

The increasing body of evidence tends to indicate some relationship between qualitative and quantitative characteristics of individual urinary microbiome and OAB symptoms in adult patients [29,69-71]. Surprisingly little is known about the possible associations between the urinary microbiome and $\mathrm{OAB}$ symptoms in the pediatric population. In fact, we were unable to identify papers that would specifically address this issue in children or adolescents.

Given the variety of etiopathological concepts and clinical presentations of OAB and the plethora of its somatic and psychological consequences in pediatric patients, studies on the role of the urinary microbiome in OAB could be of clear theoretical and practical importance. The following paragraphs may provide some basic ideas and impetus for research on the link between the urinary microbiome and OAB in children and adolescents.

From a theoretical point of view, future clinical studies could target specific quantitative and/or qualitative traits of the urinary microbiome as correlates of bladder physiology and pathophysiology assessed with the aid of a urine test, an ultrasound of the urinary tract, a bladder diary, dysfunctional elimination symptom questionnaires, and urodynamic methods. Microbiological and molecular approaches could help to identify bacterial species and 
their metabolic products directly responsible for local alterations in the urothelial milieu even in the absence of obvious symptoms of lower urinary tract infection.

From a practical point of view, it remains to be established whether qualitative and/or quantitative features of the urinary microbiome could be risk or protective factors for the development of $\mathrm{OAB}$ in pediatric patients. As clinicians are typically confronted with sick children rather than healthy at-risk individuals, one may also wish to know whether urinary microbiome fingerprints could provide some markers of OAB symptom severity and long-term prognosis in already diagnosed cases. For obvious reasons, it would be of value to correlate the history of lower urinary tract infections and cumulative antibiotic exposure with alterations in the urinary microbiome and $\mathrm{OAB}$ symptomatology.

Last but not least, future randomized clinical trials could address the role of antibiotics and probiotics in the primary or secondary prevention of $\mathrm{OAB}$ as well as in the treatment of $\mathrm{OAB}$ in children and adolescents. Gender, age, hormonal status as well as neuropsychiatric, metabolic (e.g., obesity), renal, urological, and gynecological comorbidities may pose a set of hypothetical factors modifying possible associations between the urinary microbiome and $\mathrm{OAB}$ in the pediatric population.

Author Contributions: K.K.-P. and P.B.: conception, study design, collection and interpretation of data, and manuscript writing; A.R.: collection and interpretation of data, revision of the manuscript. All authors have read and agreed to the published version of the manuscript.

Funding: This research received no external funding.

Institutional Review Board Statement: Not applicable.

Informed Consent Statement: Not applicable.

Data Availability Statement: Not applicable.

Conflicts of Interest: All the authors declared no conflict of interest.

\section{References}

1. Ramsay, S.; Bolduc, S. Review overactive bladder in children. Can. Urol. Assoc. J. 2017, 1, S74-S79. [CrossRef] [PubMed]

2. Milsom, I.; Coyne, K.S.; Nicholson, S.; Kvasz, M.; Chen, C.I.; Wein, A.J. Global prevalence and economic burden of urgency urinary incontinence: A systematic review. Eur. Urol. 2014, 65, 79-95. [CrossRef] [PubMed]

3. Bartoli, S.; Aguzzi, G.; Tarricone, R. Impact on quality of life of urinary incontinence and overactive bladder: A systematic literature review. Urology 2010, 75, 491-500. [CrossRef] [PubMed]

4. Reynolds, W.S.; Fowke, J.; Dmochowski, R. The burden of overactive bladder on US public health. Curr. Bladder Dysfunct. Rep. 2016, 11, 8-13. [CrossRef]

5. Landgraf, J.M.; Abidari, J.; Cilento, B.G., Jr.; Cooper, C.S.; Schulman, S.L.; Ortenberg, J. Coping, commitment, and attitude: Quantifying the everyday burden of enuresis on children and their families. Pediatrics 2004, 113, 334-344. [CrossRef] [PubMed]

6. Franco, I. Overactive bladder in children. Nat. Rev. Urol. 2016, 13, 520-532. [CrossRef] [PubMed]

7. Austin, P.F.; Bauer, S.B.; Bower, W.; Chase, J.; Franco, I.; Hoebeke, P.; Rittig, S.; Walle, J.V.; Von Gontard, A.; Wright, A.; et al. The standardization of terminology of lower urinary tract function in children and adolescents: Update report from the standardization committee of the International Children's Continence Society. Neurol. Urodyninamics 2016, 35, 471-481. [CrossRef]

8. Tekgul, S.; Stein, R.; Bogaert, G.; Undre, S.; Nijman, R.J.M.; Quaedackers, J.; 't Hoen, L.; Kocvara, R.; Silay, M.S.; Radmayr, C.; et al. EAU-ESPU guidelines recommendations for daytime lower urinary tract conditions in children. Eur. J. Pediatrics 2020, 179, 1069-1077. [CrossRef] [PubMed]

9. Hellerstein, S.; Zguta, A.A. Outcome of overactive bladder in children. Clin. Pediatrics 2003, 42, 553-556. [CrossRef] [PubMed]

10. Ural, Z.; Ulman, I.; Avanoglu, A. Bladder dynamics and vesicoureteral reflux: Factors associated with idiopathic lower urinary tract dysfunction in children. J. Urol. 2008, 179, 1564-1567. [CrossRef]

11. Koff, S.A.; Wagner, T.T.; Jayanthi, V.R. The relationship among dysfunctional elimination syndromes, primary vesicoureteral reflux and urinary tract infections in children. J. Urol. 1998, 160, 1019-1022. [CrossRef]

12. UpToDate. Etiology and Clinical Features of Bladder Dysfunction in Children. Available online: www-1uptodate-1com-12 h8moszo02a5.han.bg.umed.wroc.pl/contents/etiology-and-clinical-features-of-bladder-dysfunction-in-children (accessed on 2 March 2021).

13. Hellström, A.; Hanson, E.; Hansson, S.; Hjalmas, K.; Jodal, U. Micturition habits and incontinence at age 17-Reinvestigation ofa cohort studied at age 7. Br. J. Urol. 1995, 76, 231-234. [CrossRef] [PubMed] 
14. Fitzgerald, M.P.; Thom, D.H.; Wassel-Fyr, C.; Subak, L.; Brubaker, L.; Van den Eeden, S.K.; Brown, J.S. Reproductive risks for incontinence study at Kaiser research group. Childhood urinary symptoms predict adult overactive bladder symptoms. J. Urol. 2006, 175, 989-993. [CrossRef]

15. Oliveira, R.G.; Baross, U., Jr. Overactive bladder in children. Eur. Med. J. 2018, 3, 70-77.

16. Gerber, D.; Forster, C.S.; Hsieh, M. The role of the genitourinary microbiome in pediatric urology: A Review. Curr. Urol. Rep. 2018, 19, 13. [CrossRef]

17. Chung, J.M.; Lee, S.D.; Kang, D.I.; Kwon, D.D.; Kim, K.S.; Kim, S.Y.; Kim, H.G.; Moon, D.G.; Park, K.H.; Park, Y.H.; et al. Korean enuresis association. prevalence and associated factors of overactive bladder in Korean children 5-13 years old: A nationwide multicenter study. Urology 2009, 73, 63-67. [CrossRef]

18. Kajiwara, M.; Inoue, K.; Kato, M.; Usui, A.; Kurihara, M.; Usui, T. Nocturnal enuresis and overactive bladder in children: An epidemiologic study. Int. J. Urol. 2006, 13, 36-41. [CrossRef]

19. Middleton, T.; Ellsworth, P. Pharmacologic therapies for the management of non-neurogenic urinary incontinence in children. Expert. Opin. Pharmacother. 2019, 20, 2335-2352. [CrossRef]

20. Wall, D.L.L.; Heesakkers, J.P. Effectiveness of percutaneous tibial nerve stimulation in the treatment of overactive bladder syndrome. Res. Rep. Urol. 2017, 9, 145-157. [PubMed]

21. Hellström, A.; Hanson, E.; Hansson, S.; Hjalmas, K.; Jodal, U. Micturition habits and incontinence in 7-year-old Swedish school entrants. Eur. J. Pediatrics 1990, 149, 434-437. [CrossRef]

22. Sampaio, A.S.; Fraga, L.G.A.; Salomão, B.A.; Oliveira, J.B.; Seixas, C.L.; Veiga, M.L.; Netto, J.M.B.; Barroso, U. Are lower urinary tract symptoms in children associated with urinary symptoms in their mothers? J. Pediatric Urol. 2017, 13, e1-e269. [CrossRef] [PubMed]

23. Vrijens, D.; Drossaerts, J.; Van Koeveringe, G.; Van Kerrebroeck, P.; Van Os, J.; Leue, C. Affective symptoms and the overactive bladder-A systematic review. J. Psychosom. Res. 2015, 78, 95-108. [CrossRef]

24. Kim, J.W.; Kim, S.J.; Park, J.M.; Na, Y.G.; Kim, K.H. Past, present, and future in the study of neural control of the lower urinary tract. Int. Neurol. J. 2020, 24, 191-199. [CrossRef] [PubMed]

25. Farhan, B.; Chang, H.; Ahmed, A.; Zaldivair, F.; Ghoniem, G. Characterisation of urinary monocyte chemoattractant protein 1: Potential biomarker for patients with overactive bladder. Arab. J. Urol. 2019, 17, 58-60. [CrossRef]

26. Zuo, L.; Zhou, Y.; Wang, S.; Wang, B.; Gu, H.; Chen, J. Abnormal brain functional connectivity strength in the overactive bladder syndrome: A Resting-state fMRI study. Urology 2019, 131, 64-70. [CrossRef]

27. Pearce, M.M.; Hilt, E.E.; Rosenfeld, A.B.; Zilliox, M.J.; Thomas-White, K.; Fok, C.; Kliethermes, S.; Schreckenberger, P.C.; Brubaker, L.; Gai, X.; et al. The female urinary microbiome: A comparison of women with and without urgency urinary incontinence. MBio 2014, 5, e01283-14. [CrossRef]

28. Magistro, G.; Stief, C.G. The urinary tract microbiome: The answer to all our open questions? Eur. Urol. Focus 2019, 5, 36-38. [CrossRef]

29. Pearce, M.M.; Zilliox, M.J.; Rosenfeld, A.B.; Thomas-White, K.J.; Richter, H.E.; Nager, C.W.; Visco, A.G.; Nygaard, I.E.; Barber, M.D.; Schaffer, J.; et al. Pelvic floor disorders network. The female urinary microbiome in urgency urinary incontinence. Am. J. Obstet. Gynecol. 2015, 213, e1-e11. [CrossRef] [PubMed]

30. Antunes-Lopes, T.; Vale, L.; Coelho, A.M.; Silva, C.; Rieken, M.; Geavlete, B.; Rashid, T.; Rahnama'i, S.M.; Cornu, J.N.; Marcelissen, T. The role of urinary microbiota in lower urinary tract dysfunction: A systematic review. Eur. Urol. Focus 2020, 6, 361-369. [CrossRef]

31. Baethge, C.; Goldbeck-Wood, S.; Stephan Mertens, S. SANRA-A scale for the quality assessment of narrative review articles. Res. Integr. Peer Rev. 2019, 4, 5. [CrossRef]

32. Ferrari, R. Writing narrative style literature reviews. Med. Writing 2015, 24, 230-235. [CrossRef]

33. Smith, A.L. Understanding overactive bladder and urgency incontinence: What does the brain have to do with it? F1000Res. 2018, 7, F1000 Faculty Rev-1869. [CrossRef]

34. Bauer, S.B.; Yeung, C.K.; Sihoe, J.D. Voiding Dysfunction in Children: Neurogenic and Non-Neurogenic. In Campbell's Urology, 9th ed.; Kavoussi, L.R., Novick, A.C., Partin, A.W., Peters, C.A., Wein, A.J., Eds.; WB Saunders Co.: Philadelphia, PA, USA, 2007; pp. 3604-3655.

35. Sillén, U. Bladder function in healthy neonates and its development during infancy. J. Urol. 2001, 166, 2376-2381. [CrossRef]

36. Griffiths, D.; Derbyshire, S.; Stenger, A.; Resnick, N. Brain control of normal and overactive bladder. J. Urol. 2005, $174,1862-1867$. [CrossRef] [PubMed]

37. Tyagi, P.; Barclay, D.; Zamora, R.; Yoshimura, N.; Peters, K.; Vodovotz, Y.; Chancellor, M. Urine cytokines suggest an inflammatory response in the overactive bladder: A pilot study. Int. Urol. Nephrol. 2010, 42, 629-635. [CrossRef] [PubMed]

38. Lewis, D.A.; Brown, R.; Williams, J.; White, P.; Jacobson, S.K.; Marchesi, J.R.; Drake, M.J. The human urinary microbiome; bacterial DNA in voided urine of asymptomatic adults. Front. Cell. Infect. Microbiol. 2013, 3, 41. [CrossRef] [PubMed]

39. Ghoniem, G.; Faruqui, N.; Elmissiry, M.; Mahdy, A.; Abdelwahab, H.; Oommen, M.; Abdel-Mageed, A.B. Differential profile analysis of urinary cytokines in patients with overactive bladder. Int. Urogynecol. J. 2011, 22, 953-961. [CrossRef] [PubMed]

40. Al-Ghazo, M.A.; Ghalayini, I.F.; Al-Azab, R.; Hani, O.B.; Matani, Y.S.; Haddad, Y. Urodynamic detrusor overactivity in patients with overactive bladder symptoms. Int. Neurol. J. 2011, 15, 48-54. [CrossRef] [PubMed] 
41. Ptashnyk, T.; Hatzinger, M.; Zeller, F.L.; Kirschner-Hermanns, R. Overactive bladder syndrome-Focus onto detrusor overactivity. Scand. J. Urol. 2020, 55, 56-60. [CrossRef]

42. Hashim, H.; Abrams, P. Is the bladder a reliable witness for predicting detrusor overactivity? J. Urol. 2006, 175, 191-194. [CrossRef]

43. Nitti, V.W.; Kopp, Z.; Lin, A.T.L.; Moore, K.H.; Oefelein, M.; Mills, I.W. Can we predict which patient will fail drug treatment for overactive bladder? At think tank discussion. Neurourol. Urodyn. 2010, 29, 652-657. [CrossRef] [PubMed]

44. Schulman, S.L.; Quinn, C.K.; Plachter, N.; Kodman-Jones, C. Comprehensive management of dysfunctional voiding. Pediatrics 1999, 103, E31. [CrossRef] [PubMed]

45. Hoebeke, P.; Van Laecke, E.; Van Camp, C.; Raes, A.; Van De Walle, J. One thousand video-urodynamic studies in children with non-neurogenic bladder sphincter dysfunction. BJU Int. 2001, 87, 575-580. [CrossRef]

46. Bael, A.; Lax, H.; Jong, D.T.P.; Hoebeke, P.; Nijman, R.J.; Sixt, R.; Verhulst, J.; Hirche, H.; Van Gool, J.D. European bladder dysfunction study (European Union BMH1-CT94-1006). The relevance of urodynamic studies for urge syndrome and dysfunctional voiding: A multicenter controlled trial in children. J. Urol. 2008, 180, 1486-1493. [CrossRef]

47. Benson, A.K.; Kelly, S.A.; Legge, R.; Ma, F.; Low, S.J.; Kim, J.; Zhang, M.; Oh, P.L.; Nehrenberg, D.; Hua, K.; et al. Individuality in gut microbiota composition is a complex polygenic trait shaped by multiple environmental and host genetic factors. Proc. Natl. Acad. Sci. USA 2010, 107, 18933-18938. [CrossRef] [PubMed]

48. Cho, I.; Blaser, M.J. The human microbiome: At the interface of health and disease. Nat. Rev. Genet. 2012, 13, 260-270. [CrossRef] [PubMed]

49. Dominguez-Bello, M.G.; Costello, E.K.; Contreras, M.; Magris, M.; Hidalgo, G.; Fierer, N.; Knight, R. Delivery mode shapes the acquisition and structure of the initial microbiota across multiple body habitats in newborns. Proc. Natl. Acad. Sci. USA 2010, 107, 11971-11975. [CrossRef]

50. Asnicar, F.; Manara, S.; Zolfo, M.; Truong, D.T.; Scholz, M.; Armanini, F.; Ferretti, P.; Gorfer, V.; Pedrotti, A.; Tett, A.; et al. Studying vertical microbiome transmission from mothers to infants by strain-level metagenomic profiling. mSystems 2017, 2, e00164-16. [CrossRef]

51. Aragón, I.M.; Herrera-Imbroda, B.; Queipo-Ortuño, M.I.; Castillo, E.; Del Moral, J.S.; Gómez-Millán, J.; Yucel, G.; Lara, M.F. The urinary tract microbiome in health and disease. Eur. Urol. Focus 2018, 4, 128-138. [CrossRef]

52. Ackerman, A.L.; Chai, T.C. The bladder is not sterile: An update on the urinary microbiome. Curr. Bladder Dysfunct. Rep. 2019, 14, 331-341. [CrossRef]

53. Wolfe, A.J.; Toh, E.; Shibata, N.; Rong, R.; Kenton, K.; Fitzgerald, M.P.; Mueller, E.R.; Schreckenberger, P.; Dong, Q.; Nelson, D.E.; et al. Evidence of uncultivated bacteria in the adult female bladder. J. Clin. Microbiol. 2012, 50, 1376-1383. [CrossRef] [PubMed]

54. Hilt, E.E.; McKinley, K.; Pearce, M.M.; Rosenfeld, A.B.; Zilliox, M.J.; Mueller, E.R.; Brubaker, L.; Gai, X.; Wolfe, A.J.; Schreckenberger, P.C. Urine is not sterile: Use of enhanced urine culture techniques to detect resident bacterial flora in the adult female bladder. J. Clin. Microbiol. 2014, 52, 871-876. [CrossRef] [PubMed]

55. Fouts, D.E.; Pieper, R.; Szpakowski, S.; Pohl, H.; Knoblach, S.; Suh, M.J.; Huang, S.H.; Ljungberg, I.; Sprague, B.M.; Lucas, S.K.; et al. Integrated next-generation sequencing of $16 \mathrm{~S}$ rDNA and metaproteomics differentiate the healthy urine microbiome from asymptomatic bacteriuria in neuropathic bladder associated with spinal cord injury. J. Transl. Med. 2012, 10, 174. [CrossRef] [PubMed]

56. Morand, A.; Cornu, F.; Dufour, J.C.; Tsimaratos, M.; Lagier, J.C.; Raoult, D. Human bacterial repertoire of the urinary tract: A potential paradigm shift. J. Clin. Microbiol. 2019, 57, e00675-18. [CrossRef] [PubMed]

57. Kinneman, L.; Zhu, W.; Wong, W.S.W.; Clemency, N.; Provenzano, M.; Vilboux, T.; Jane't, K.; Seo-Mayer, P.; Levorson, R.; Kou, M.; et al. Assessment of the urinary microbiome in children younger than 48 months. Pediatric Infect. Dis. J. 2020, 39, 565-570. [CrossRef]

58. Curley, T.; Forster, C.S. Recurrent UTIs in girls: What is the role of the microbiome? Urology 2020. [CrossRef] [PubMed]

59. Popović, V.B.; Šitum, M.; Chow, C.-E.T.; Chan, L.S.; Roje, B.; Terzić, J. The urinary microbiome associated with bladder cancer. Sci. Rep. 2018, 8, 12157. [CrossRef] [PubMed]

60. Hickey, R.J.; Zhou, X.; Settles, M.L.; Erb, J.; Malone, K.; Hansmann, M.A.; Shew, M.L.; Van Der Pol, B.; Fortenberry, D.J.; Forney, L.J. Vaginal microbiota of adolescent girls prior to the onset of menarche resemble those of reproductive-age women. MBio 2015, 6, e00097-15. [CrossRef]

61. Smith, S.B.; Ravel, J. The vaginal microbiota, host defence and reproductive physiology. J. Physiol. 2017, 595, 451-463. [CrossRef] [PubMed]

62. Komesu, Y.M.; Dinwiddie, D.L.; Richter, H.E.; Lukacz, E.S.; Sung, V.W.; Siddiqui, N.Y.; Zyczynski, H.M.; Ridgeway, B.; Rogers, R.G.; Arya, L.A.; et al. Pelvic floor disorders network. Defining the relationship between vaginal and urinary microbiomes. Am. J. Obstet. Gynecol. 2020, 222, e1-e154. [CrossRef]

63. Gorbachinsky, I.; Sherertz, R.; Russell, G.; Krane, L.S.; Hodges, S.J. Altered perineal microbiome is associated with vulvovaginitis and urinary tract infection in preadolescent girls. Ther. Adv. Urol. 2014, 6, 224-229. [CrossRef]

64. Lucas, E.J.; Ching, C.B.; Saraswat, S.; Dabdoub, S.M.; Kumar, P.P.; Justice, S.S. Acquisition, divergence, and personalization of the female perineal microbiomes are driven by developmental milestones and disrupted by urinary tract infection: A pilot study. Front. Pediatrics 2020, 8, 542413. [CrossRef] [PubMed]

65. Forster, C.S.; Panchapakesan, K.; Stroud, C.; Banerjee, P.; Gordish-Dressman, H.; Hsieh, M.H. A cross-sectional analysis of the urine microbiome of children with neuropathic bladders. J. Pediatrics Urol. 2020, 16, e1-e593. [CrossRef] [PubMed] 
66. Kassiri, B.; Shrestha, E.; Kasprenski, M.; Antonescu, C.; Florea, L.D.; Sfanos, K.S.; Wang, M.H. A prospective study of the urinary and gastrointestinal microbiome in prepubertal males. Urology 2019, 13, 204-210. [CrossRef]

67. Kispal, Z.F.; Vajda, P.; Kardos, D.; Klymiuk, I.; Moissl-Eichinger, C.; Castellani, C.; Singer, G.; Till, H. The local microbiome after pediatric bladder augmentation: Intestinal segments and the native urinary bladder host similar mucosal microbiota. J. Pediatrics Urol. 2019, 15, e1-e30. [CrossRef] [PubMed]

68. Ollberding, N.J.; Völgyi, E.; Macaluso, M.; Kumar, R.; Morrow, C.; Tylavsky, F.A.; Piyathilake, C.J. Urinary microbiota associated with preterm birth: Results from the conditions affecting neurocognitive development and learning in early childhood (CANDLE) study. PLoS ONE 2016, 11, e0162302. [CrossRef] [PubMed]

69. Karstens, L.; Asquith, M.; Davin, S.; Stauffer, P.; Fair, D.; Gregory, W.T.; Rosenbaum, J.T.; McWeeney, S.K.; Nardos, R. Does the urinary microbiome play a role in urgency urinary incontinence and its severity? Front. Cell. Infect. Microbiol. 2016, 6, 78. [CrossRef] [PubMed]

70. Curtiss, N.; Balachandran, A.; Krska, L.; Peppiatt-Wildman, C.; Wildman, S.; Duckett, J. A case controlled study examining the bladder microbiome in women with overactive bladder (OAB) and healthy controls. Eur. J. Obstet. Gynecol. Reprod. Biol. 2017, 214, 31-35. [CrossRef] [PubMed]

71. Thomas-White, K.J.; Hilt, E.E.; Fok, C.; Pearce, M.M.; Mueller, E.R.; Kliethermes, S.; Jacobs, K.; Zilliox, M.J.; Brincat, C.; Price, T.K.; et al. Incontinence medication response relates to the female urinary microbiota. Int. Urogynecol. J. Pelvic Floor Dysfunct. 2016, 27, 723-733. [CrossRef]

72. Dalghi, M.G.; Montalbetti, N.; Carattino, M.D.; Apodaca, G. The urothelium: Life in a liquid environment. Physiol. Rev. 2020, 100, 1621-1705. [CrossRef]

73. Roberts, M.W.G.; Sui, G.; Wu, R.; Rong, W.; Wildman, S.; Montgomery, B.; Ali, A.; Langley, S.; Ruggieri, M.R., Sr.; Wu, C. TRPV4 receptor as a functional sensory molecule in bladder urothelium: Stretch-independent, tissue-specific actions and pathological implications. FASEB J. 2020, 34, 263-286. [CrossRef] [PubMed] 